\title{
Poziom ubóstwa w krajach nowo przyjętych do Unii Europejskiej
}

\section{Wprowadzenie}

Problem ubóstwa i wykluczenia społecznego znalazł się w obszarze wspólnego zainteresowania krajów Unii Europejskiej ze względu na rozległe skutki tych zjawisk. Polityka społeczna, ograniczajacca oddziaływanie wymienionych problemów na gospodarkę, jest czynnikiem sprzyjającym rozwojowi społeczeństwa.

Podczas szczytu lizbońskiego w 2000 r. uznano poziom ubóstwa w poszczególnych krajach Unii Europejskiej za zbyt wysoki i stanowiący jedną z głównych przeszkód w rozwoju. Kraje członkowskie zadecydowały o rozpoczęciu wspólnych działań w zwalczaniu ubóstwa i wykluczenia społecznego. Przyjęto nowy model działania oparty na otwartej metodzie koordynacji ${ }^{1}$ w narodowych planach działań na rzecz integracji społecznej. Opracowano „Wspólnotowy program działań na rzecz zwalczania wykluczenia społecznego" w latach 2002-2006. Jego celem jest wspieranie wspólpracy pomiędzy państwami członkowskim i zwiększenie skuteczności przeciwdziałania wykluczeniu społecznemu. Kraje kandydujące do Unii Europejskiej mogły również uczestniczyć w jego realizacji. Kandydaci na nowych członków Unii Europejskiej zobowiązali się do przygotowania razem z Komisją Europejską tzw. wspólnych memorandów w sprawie integracji społecznej (JIM - Joint Inclusion Memoranda). Ich celem było umożliwienie pełnego uczestnictwa w otwartej metodzie koordynacji już od pierwszego dnia członkostwa.

Trwały wzrost gospodarczy oraz zwiększanie zatrudnienia jest zasadniczym, ale niewystarczającym środkiem zapewniającym spójność społeczną. Inwestowanie w stabilne zatrudnienie i w skuteczną w działaniu politykę społeczną służy budowaniu konkurencyjnego oraz opartego na wiedzy społeczeństwa dla wszystkich.

\footnotetext{
${ }^{1}$ Termin ten używany jest powszechnie do określania tej metody koordynacji działań.
} 


\section{Pojęcie ubóstwa i wykluczenia społecznego}

Przy opracowaniu strategii zwalczania wykluczenia społecznego ważne jest zdefiniowanie tego zjawiska. Jest to zadanie trudne, gdyż pojęcie może obejmować kilka nakładajacych się na siebie wymiarów marginalizacji.

W dokumencie powołującym Zespół Zadaniowy ds. Reintegracji Społecznej w Polsce została przyjęta następująca definicja wykluczenia społecznego: ,jest to brak lub ograniczenie możliwości uczestnictwa, wpływania i korzystania $\mathrm{z}$ podstawowych instytucji publicznych i rynków, które powinny być dostępne dla wszystkich, a w szczególności dla osób ubogich"2. Wykluczenie społeczne i ubóstwo ściśle wiążą się ze sobą, nie są jednak pojęciami równoważnymi. Osoby wykluczone nie muszą być ubogie, a osoby ubogie niekoniecznie sq̨ wykluczone. W krajach Europy Zachodniej mierzy się jedynie ubóstwo relatywne, które nie zawsze prowadzi do wykluczenia społecznego. Kategoria powyższa oznacza jedynie pogorszenie sytuacji pojedynczego gospodarstwa domowego w stosunku do średniego poziomu życia w danym kraju.

W celu ujednolicenia pojmowania zjawisk ubóstwa i wykluczenia społecznego przyjęto na posiedzeniu Komisji Europejskiej w Laeken w 2001 r. 18 wskaźników, służących pomiarowi omawianych zjawisk oraz będących podstawą oceny postępów osiaganych przez państwa członkowskie w realizowaniu unijnych celów. Wskaźniki obejmują najistotniejsze czynniki prowadzące do wykluczenia społecznego: ubóstwo dochodowe, poziom bezrobocia, ochronę zdrowia oraz edukację.

W artykule przedstawiono poziom wybranych wskaźników dotyczących ubóstwa dochodowego oraz rynku pracy w krajach nowych członków Unii Europejskiej. Metoda obliczania wskaźników „lejkenowskich” w nowo przyjętych państwach członkowskich jest taka sama, jak w całej Unii, jednak wskaźniki liczone dla nowych i starych państw członkowskich nie są w pełni porównywalne. Dane do obliczania wskaźników w byłej Unii pochodziły $\mathrm{z}$ bardzo wyczerpujących badań budżetów gospodarstw domowych, które nie zawsze prowadzono w nowych krajach członkowskich. Starano się zachować porównywalność danych w jak największym stopniu, jednak nie zawsze było to możliwe. Zebrane dane dotyczą wszystkich „,nowych" państw oprócz Słowacji ${ }^{3}$.

\footnotetext{
${ }^{2}$ Narodowa Strategia Integracji Społecznej dla Polski - dokument przygotowany przez Zespół Zadaniowy do spraw Reintegracji Społecznej, któremu przewodniczył Minister Gospodarki, Pracy i Polityki Społecznej Jerzy Hausner.

${ }^{3} \mathrm{~W}$ artykule zastosowano następujące symbole oznaczające nazwy poszczególnych krajów: $\mathrm{CZ}$ - Czechy; EE - Estonia, CY - Cypr, LV - Łotwa, LT - Litwa, HU - Węgry, MT - Malta, PL Polska, SI - Słowenia, SK - Słowacja. Dane dla poszczególnych krajów dotyczyły innych okresów badawczych: CY - 1997, MT, SI - 2000, CZ, LT, HU, PL - 2001, EE, LV - 2002. Skrót EU10 oznacza średni poziom wskaźnika w nowych krajach członkowskich, a EU15 - w starych krajach czlonkowskich w $2001 \mathrm{r}$.
} 


\section{Poziom i zasięg ubóstwa w dziewięciu nowych krajach Unii Europejskiej}

Ubóstwo i wykluczenie społeczne są zjawiskami o znacznym zasięgu w nowych krajach członkowskich, w których duża część społeczeństwa osiąga niskie dochody i doświadcza deprywacji w różnych dziedzinach życia społeczno-gospodarczego. Nowo opracowane wskaźniki dotyczące wykluczenia społecznego dostarczyły jasnego i dokładnego obrazu rozmiaru ubóstwa $\mathrm{i}$ innych aspektów wykluczenia. Pomiędzy poszczególnymi krajami istnieje duże zróżnicowanie w poziomie tych zjawisk.

Zasięg ubóstwa relatywnego ${ }^{4}$ wyraża procentowy udział osób znajdujących się w sferze ubóstwa. Jako wartość graniczną przyjęto $60 \%$ mediany dochodów ekwiwalentnych osiaganych w danym kraju ${ }^{5}$. Przeciętny zasięg ubóstwa w nowych krajach członkowskich (rys. 1) był nieznacznie mniejszy (13\%) niż w pozostałych krajach Unii Europejskiej (15\%). Można było tego oczekiwać ze względu na niższy poziom dochodów uzyskiwanych w nowych krajach członkowskich. Jednakże w Estonii (18\%), na Litwie (17\%), Cyprze i Łotwie (16\%) poziom wskaźnika przekroczył średnią „starej" Unii, a w Polsce i na Malcie miał takim sam poziom $-15 \%$. Płeć nie miała znaczącego wpływu na poziom wskaźnika - przeciętnie zagrożenie ubóstwem było prawie takie samo dla kobiet (13\%), jak i dla mężczyzn (14\%), aczkolwiek w Czechach, na Cyprze i w Słowenii kobiety częściej znajdowały się poniżej granicy ubóstwa.

\section{Ubóstwo w różnych grupach ludności}

Podobnie jak w krajach EU15, zagrożenie ubóstwem było bardzo wysökie wśród osób bezrobotnych (36\%). Największymi poziomami wskánika charakteryzowały się Malta (50\%) i Estonia (48\%), a najniższymi Cypr (23\%), Czechy i Węgry (31\%). Jednocześnie należy zauważyć, że posiadanie pracy nie eliminuje całkowicie zagrożenia ubóstwem zarówno w krajach EU15, jak i w nowej ,Dziewiątce".

\footnotetext{
${ }^{4}$ Przy określaniu ubóstwa relatywnego standard życia pojedynczej osoby lub gospodarstwa domowego porównuje się $\mathrm{w} z$ przeciętnym poziomem życia społeczeństwa $\mathrm{w}$ danym kraju.

${ }^{5}$ Wyznaczenie wattości granicznej pozwala oddzielić populację ubogich od reszty społeczeństwa. Zastosowanie mediany w wyznaczaniu granicy ubóstwa uzasadnia się jej lepszym mierzeniem tendencji głównej. Na jej poziom nie mają bowiem wpływu wartości-skrajne - w przeciwieństwie do poziomu średniej arytmetycznej. Dochody ekwiwalentne pózwalają wyelimino-. wać wpływ, jaki na wysokość dochodów ma skład społeczno-demografíczny gospodarstwa domowego.
} 


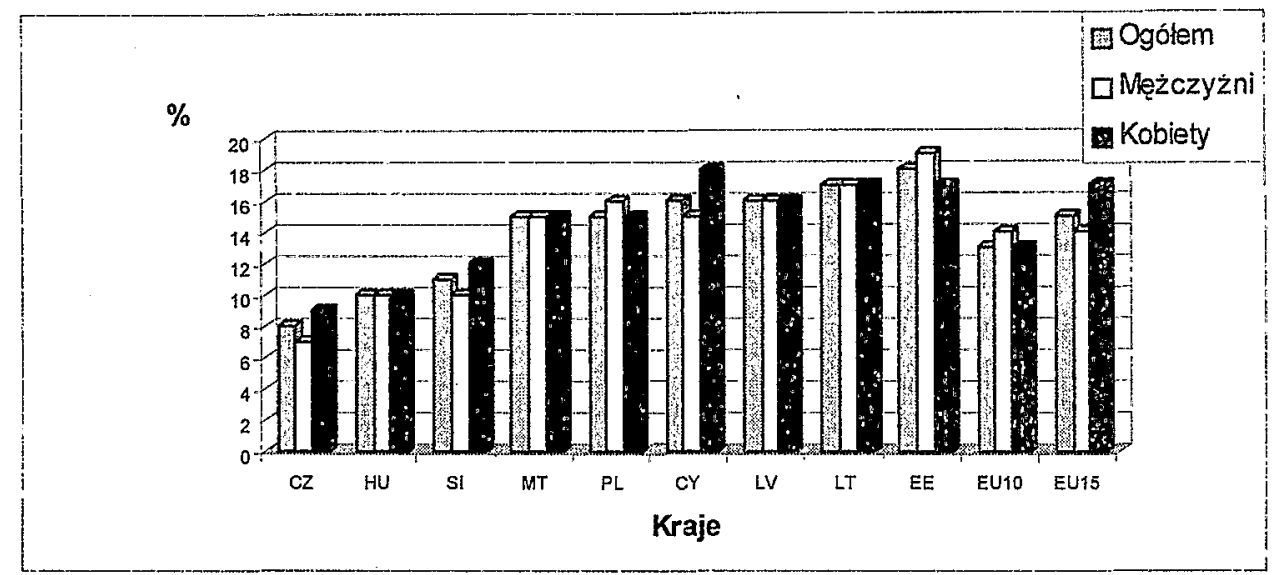

\section{Rysunek 1}

Zasięg ubóstwa relatywnego w nowych krajach Unil Europejskiej (w \%)

Źródło: Commission of the European Communities; Commission Staff Working Paper, Social Inclusion in the New Member States, A Synthesis of the Joint Memoranda on Social Inclusion; Brussels, 22.6.2004 SEC (2004)848; dane dla poszczególnych krajów dotyczyły innych okresów badawczych: CY - 1997, MT, SI - 2000, CZ, LT, HU, PL 2001, EE, LV - 2002.

Zaskakująco duży odsetek osób pracujących na własny rachunek znajdował się w sferze ubóstwa na Litwie (33\%) i Lotwie (22\%). Najlepszą sytuacje miały osoby prowadzące własną działalność na Malcie i Węgrzech. Wśród emerytów największy zasięg ubóstwa występował na Cyprze - aż 62\%. Tak duża liczba może sugerować niskie świadczenia emerytalne w tym kraju. Najlepszą sytuację natomiast mieli emeryci w Czechach, gdzie tylko 5\% żyło poniżej granicy ubóstwa (tab. 1).

\section{Tabela 1}

Zasięg ubóstwa relatywnego według rodzaju aktywności ekonomicznej w nowych krajach Unii Europejskiej

\begin{tabular}{|c|c|c|c|c|c|c|c|c|c|c|c|}
\hline \multirow[b]{2}{*}{ Wyszczególnienie } & \multicolumn{11}{|c|}{$\begin{array}{c}\text { Udział osób w sferze ubóstwa relatywnego w krajach Unii } \\
\text { Europejskiej [\%] }\end{array}$} \\
\hline & $C Z$ & $\mathrm{EE}$ & CY & LV & LT & $\mathrm{HU}$ & MT & $\mathrm{PL}$ & $\mathrm{SI}$ & EU1C & EU15 \\
\hline Pracownicy & 3 & 9 & 5 & 9 & 9 & 5 & 6 & 7 & 4 & 6 & 6 \\
\hline $\begin{array}{l}\text { Pracujący na własny } \\
\text { rachunek }\end{array}$ & 5 & 13 & 9 & 22 & 33 & 3 & 1 & 19 & 10 & 15 & 16 \\
\hline Bezrobotni & 31 & 48 & 23 & 42 & 41 & 31 & 50 & 37 & 43 & 36 & 38 \\
\hline Emeryci & 5 & 21 & 62 & 13 & .13 & 9 & 18 & 7 & 15 & 9 & 17 \\
\hline Bierni zawodowo/inni & 11 & 28 & 20 & 27 & 20 & 15 & 18 & $\overline{18}$ & 19 & 17 & 25 \\
\hline
\end{tabular}

Źródlo: jak na rysunku 1. 
Z przeprowadzonej analizy wynika, że zasięg ubóstwa wśród dzieci (w wieku 0-15 lat) w nowych krajach członkowskich był dość wysoki (18\%). Ubóstwo najbardziej dotknęło dzieci w Polsce i na Malcie oraz na Litwie, gdzie co piąte $\mathrm{z}$ nich $\mathrm{znajdowało} \mathrm{się} \mathrm{w}$ tej sferze. Jest to zjawisko bardzo niepokojące, gdyż może negatywnie wpłynąc na rozwój fizyczny i emocjonalny dziecka. Dodatkowo, dzieci wychowywane $w$ rodzinach ubogich często nie mają możliwości wydostania się z biedy, nie uczą się odpowiednich postaw życiowych, co może prowadzić do zjawiska tzw. dziedziczenia ubóstwa. Najmniej procentowo dzieci ubogich w grupie 0-15 lat miała Słowenia, gdzie zasięg ubóstwa był dwukrotnie mniejszy niż przeciętna europejska (tab. 2).

Duży zasięg ubóstwa wśród młodych osób wystapił w Estonii i na Litwie, gdzie dotyczyło ono co szóstej osoby w wieku 16-24 lata. Mogło to mieć wpływ na kształtowanie się postaw życiowych osób tej grupy, które wchodza w dorosłe życie z problemami materialnymi. Często taka sytuacja zniechęca do podejmowania prób wydobycia się ze sfery niedostatku.

\section{Tabela 2}

Zasięg ubóstwa relatywnego $w$ grupach wiekowych w nowych krajach członkowskich Unii Europejskiej

\begin{tabular}{|l|c|c|c|c|c|c|c|c|c|c|c|}
\hline \multirow{3}{*}{ Wiek } & \multicolumn{8}{|c|}{ Udział osób w sferze ubóstwa relatywnego w krajach } \\
\cline { 2 - 15 } & CZ & EE & CY & LV & LT & HU & MT & PL & SI & EU10 & EU15 \\
\hline Ogółem & 8 & 18 & 16 & 16 & 17 & 10 & 15 & 15 & 11 & 13 & 15 \\
\hline $0-15$ & 12 & 18 & 12 & 19 & 20 & 14 & 21 & 21 & 9 & 18 & 19 \\
\hline $16-24$ & 10 & 21 & 9 & 18 & 21 & 12 & 10 & 19 & 11 & 16 & 19 \\
\hline $25-49$ & 7 & 17 & 9 & 16 & 17 & 9 & 14 & 16 & 9 & 14 & 12 \\
\hline $50-64$ & 4 & 19 & 15 & 17 & 15 & 7 & 12 & 10 & 11 & 9 & 12 \\
\hline 65 i więcej & 6 & 16 & 58 & 10 & 12 & 9 & 20 & 6 & 21 & 8 & 19 \\
\hline
\end{tabular}

Żródlo: jak na rysunku 1.

Do grupy wiekowej najmniej zagrożonej ubóstwem należały osoby starsze (65 lat i więcej). Zasięg ubóstwa w tej grupie był o 5 p.p. mniejszy niż przeciętny dla całego społeczeństwa. Najlepsza sytuacja wystapiła w Polsce oraz Czechach, gdzie jedynie co dwudziesta osoba osiagała dochód ekwiwalentny niższy niż $60 \%$ mediany dochodów w swoim kraju. Poziom świadczeń emerytalnych w tych dwóch krajach chroni przed wejściem w sferę ubóstwa. Na Cyprze sytuacja dochodowa osób starszych była bardzo zła, ponieważ w kraju tym więcej niż połowa osób w wieku ponad 65 lat żyła w sferze ubóstwa. Świadczyć to może o niskim poziomie zabezpieczeń społecznych ludzi starszych. 
Biorąc pod uwage typ biologiczny gospodarstwa domowego, największym zasięgiem ubóstwa charakteryzowały się rodziny wielodzietne i osoby samotnie wychowujące dzieci. Najgorsza sytuacja wystapiła na Malcie, gdzie co drugie gospodarstwo domowe osoby samotnie wychowującej dziecko znajdowało się W sferze ubóstwa. W Polsce natomiast prawie co trzecia rodzina mająca troje lub więcej dzieci nie osiagała dochodu powyżej granicy ubóstwa. Na Cyprze bardzo wysoki poziom zagrożenia ubóstwem występował wśród jednoosobowych gospodarstw domowych prowadzonych przez osoby w wieku 65 lat i więcej, gdzie ponad $80 \%$ osób z tej grupy było dotkniętych ubóstwem relatywnym. Znajdowało się $w$ nim również częściej niż co drugie bezdzietne dwuosobowe gospodarstwo domowe, w którym przynajmniej jedna osoba miała więcej niż 65 lat (tab. 3).

\section{Tabela 3}

Zasięg ubóstwa relatywnego według typu biologicznego gospodarstwa domowego w nowych krajach członkowskich Unii Europejskiej

\begin{tabular}{|c|c|c|c|c|c|c|c|c|c|c|c|c|}
\hline \multirow{2}{*}{$\begin{array}{l}\text { Typ gospodar- } \\
\text { stwa domowe: } \\
\text { go }\end{array}$} & \multirow{2}{*}{ Inne kryteria } & \multicolumn{11}{|c|}{$\begin{array}{l}\text { Udział osób w sferze ubóstwa relatywnego w krajach Unii Euro- } \\
\text { pejskiej [\%] }\end{array}$} \\
\hline & & $\mathrm{CZ}$ & EE & $\mathrm{CY}$ & LV & LT & $\mathrm{HU}$ & MT & $\mathrm{PL}$ & SI & EU10 & EU15 \\
\hline \multirow{4}{*}{ 1-osobowe } & ogółem & 14 & 35 & 64 & 21 & 24 & 15 & 25 & 10 & 35 & 14 & 25 \\
\hline & $w$ wieku $<30$ lat & 14 & 39 & 25 & 16 & 14 & 10 & 34 & 5 & 26 & 9 & 32 \\
\hline & w wieku 30-64 lata & 16 & 36 & 34 & 27 & 27 & 16 & 23 & 14 & 26 & 17 & 15 \\
\hline & $\begin{array}{l}\text { w wieku } 65 \text { lat } \\
\text { i wiecej }\end{array}$ & 12 & 33 & 83 & 17 & 22 & 15 & 25 & 6 & 42 & 12 & 29 \\
\hline \multirow{2}{*}{$\begin{array}{l}2 \text { dorosłych bez } \\
\text { dzieci }\end{array}$} & $\begin{array}{l}\text { co najmniej jedna } \\
\text { osoba w wieku } \\
65 \text { lat i wiecej }\end{array}$ & 3 & 15 & 58 & 7 & 8 & 5 & 25 & 8 & 18 & 8 & 16 \\
\hline & $\begin{array}{l}\text { obydwoje w wieku } \\
<65 \text { lat }\end{array}$ & 3 & 7 & 11 & 15 & 14 & 6 & 11 & 8 & 12 & 8 & 10 \\
\hline Inne bez dzieci & & 7 & 13 & 10 & 10 & 14 & 4 & 5 & 9 & 8 & 8 & 9 \\
\hline samotni rodzice & $\begin{array}{l}\text { co najmniej jedno } \\
\text { dziecko }\end{array}$ & 27 & 35 & 41 & 35 & 23 & 18 & 55 & 19 & 20 & 21 & 35 \\
\hline $\begin{array}{l}2 \text { dorosłych, } 1 \\
\text { dziecko }\end{array}$ & & 6 & 13 & 6 & 14 & 14 & 8 & 13 & 9 & 12 & 9 & 10 \\
\hline $\begin{array}{l}2 \text { dorostych, } 2 \\
\text { dzieci }\end{array}$ & & 6 & 15 & 9 & 19 & 17 & 12 & 16 & 14 & 6 & 13 & 13 \\
\hline $\begin{array}{l}2 \text { dorosłych, } 3 i \\
\text { więcej dzieci }\end{array}$ & & 18 & 21 & 16 & 22 & 27 & 22 & 29 & 32 & 12 & 27 & 27 \\
\hline Inne $z$ dziećmi & & 10 & 15 & 6 & 15 & 19 & 8 & 8 & 19 & 9 & 15 & 16 \\
\hline
\end{tabular}

Źródło: jak na rysunku 1. 
Osoby poniżej 30 lat częściej były dotknięte ubóstwem w krajach „piętnastki" niż w nowych krajach członkowskich. Wystappiła pomiędzy tymi grupami państw dosyć znaczna różnica, gdyż przeciętna dla Unii z 15 krajami wynosiła $32 \%$, podczas gdy średnio w przypadku nowych członków zaledwie co dziesiąta osoba była dotknięta ubóstwem. W najlepszej sytuacji dochodowej w omawianych krajach znajdowały się bezdzietne dwuosobowe gospodarstwa domowe, niezależnie od wieku członków tych gospodarstw ( $\mathrm{z}$ wyjątkiem Malty).

\section{Poziom zróżnicowania dochodowego}

Większość wskaźników dotyczących ubóstwa odnosi się do najsłabszej dochodowo grupy ludności. Rozkład dochodów na podstawie zróżnicowania kwintylowego pokazuje relacje między grupami ludności osiągającej najniższe i najwyższe dochody. Społeczeństwo zostało uszeregowane według wielkości osiaganych dochodów ekwiwalentnych, a następnie podzielone na pięć równych grup. Współczynnik S80/S20 pozwala porównać dla każdego kraju całkowity dochód ekwiwalentny najwyższego kwintyla dochodowego (20\% społeczeństwa $\mathrm{z}$ najwyższymi dochodami ekwiwalentnymi) z najniższym kwintylem dochodowym ( $20 \%$ osób osiągających najniższe dochody ekwiwalentne).

Najwyższa wartość badanego współczynnika występowała w Estonii, co świadczyło o dużych rozpiętościach w rozkładzie dochodów. Najbardziej zamożni dysponowali 6,3 razy większym dochodem niż najubożsi. W Estonii wystąpił również największy pośród nowo przyjętych państw zasięg ubóstwa, co dodatkowo potwierdza dużą różnicę w poziomie życia ludności najubożej i najbardziej zamożnej. Najmniejsze dysproporcje zaobserwowano w Słowenii, gdzie wartość współczynnika była zdecydowanie niższa od średniej z krajów byłej „piętnastki” (rys. 2).

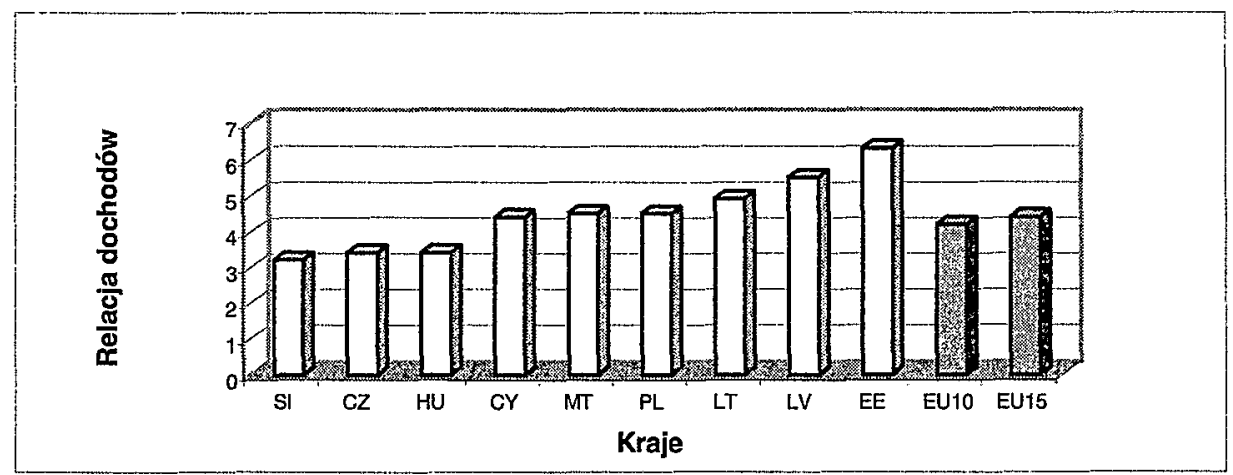

\section{Rysunek 2}

Rozkład dochodów w nowych krajach członkowskich Unii Europejskiej

Źródło: jak w na rysunku 1. 
Równość rozkładu dochodów w społeczeństwie można ocenić, stosując współczynnik Giniego, bazujący na krzywej Lorenza ${ }^{6}$.

Najmniejsza wartość współczynnika wystapiła w Słowenii (22\%) i na Węgrzech (23\%), co świadczyło o większej równości dochodów w tych krajach pośród nowo przyjętych państw do Unii Europejskiej. Wartość współczynnika w Słowenii i na Węgrzech była również niższa niż przeciętna w krajach ,piętnastki”. Największa nierówność rozkładu dochodów wystąpiła w Estonii $(35 \%)$ i na Litwie (34\%) (rys. 3).

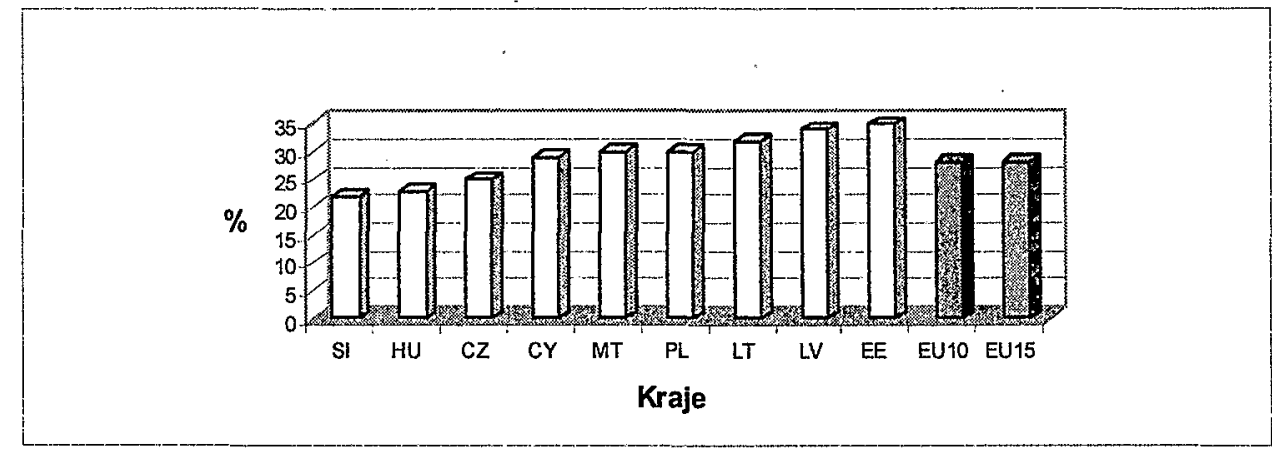

\section{Rysunek 3}

Współczynnik Giniego w nowych krajach członkowskich Unii Europejskiej Źródlo: jak na rysunku 1.

Wskaźnik głębokości ubóstwa ${ }^{7}$ służy do dokładnego określenia natężenia tego zjawiska. Największa wartość wskaźnika wystąpiła w Estonii i na Cyprze, gdzie połowa ludności dysponowała dochodem o $24 \%$ mniejszym niż wynosi wartość mediany dochodów przyjętych jako granica ubóstwa (rys. 4). Innymi słowy, ponad połowa osób ubogich w tych krajach osiagała dochody mniejsze niż 36\% mediany. Najmniejsza głębokość ubóstwa występowała w Czechach i Węgrzech $-16 \%$.

\footnotetext{
${ }^{6}$ Przy całkowicie równym podziale dochodów w społeczeństwie wartość współczynnika wynosiłaby $0 \%$, przy całkowitej nierówności (jedna osoba uzyskuje całych dochód) - $100 \%$. Im mniejszy poziom współczynnika, tym podział dochodów w społeczeństwie jest bardziej wyrównany.

${ }^{7}$ Przedstawiany jest on najczęściej za pomocą mediany luki dochodowej. Informuje, o ile procent mediana dochodów ekwiwalentnych ubogich gospodarstw domowych różni się od wartości mediany przyjętej jako granica ubóstwa.
} 


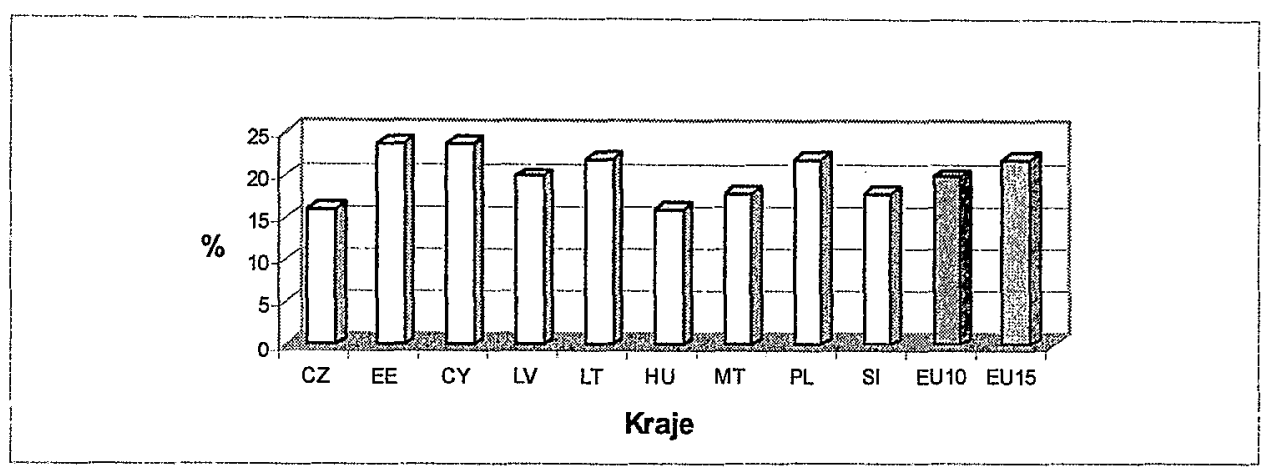

\section{Rysunek 4}

Głębokość ubóstwa w nowych krajach członkowskich Unii Europejskiej Źródło: jak na rysunku 1.

\section{Transfery a zasięg ubóstwa}

Jednym z podstawowych instrumentów zwalczania ubóstwa i zapobiegania temu zjawisku są transfery społeczne. Badając zasięg ubóstwa na podstawie dochodów gospodarstw domowych bez uwzględnienia transferów i po ich doliczeniu można ocenić rolę polityki społecznej w danym kraju. Gdyby w nowych państwach członkowskich nie istniały żadne transfery, przeciętny zasięg ubóstwa byłby ponadtrzykrotnie większy. Największa różnica wystąpiła w Czechach, gdzie transfery społeczne zmniejszyły zasięg ubóstwa ponadczterokrotnie (z 36 do 8\%). Podobną różnicą charakteryzował się zasięg ubóstwa na Węgrzech (zmiana z 44 do 10\%). Najmniejszy wpływ na obniżenie zasięgu ubóstwa miały transfery społeczne na Cyprze, gdzie na skutek transferów społecznych zasięg ubóstwa zmniejszył się 1,5-krotnie (rys. 5).

Do transferów społecznych zalicza się emerytury, które często nie są traktowane jako jeden ze składników dochodu, ale jako dochód podstawowy. Dlatego rozważa się wpływ innych niż emerytury i renty rodzinne transferów społecznych na zmniejszenie rozmiarów ubóstwa. Najmniejsza różnica w poziomie wskaźnika wystapiła na Cyprze - 2 p.p., największa w Czechach, Polsce i na Węgrzech. W krajach tych zasięg ubóstwa dzięki transferom innym niż emerytury i renty rodzinne zmniejszył się dwukrotnie. 


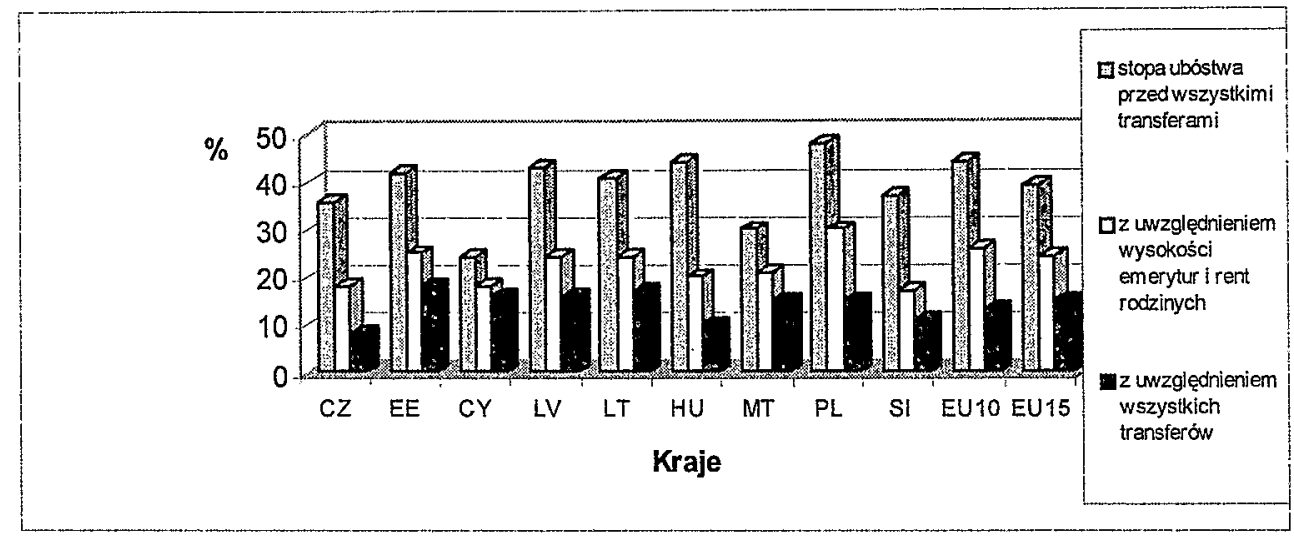

\section{Rysunek 5}

Zasięg ubóstwa przed uwzględnieniem i po uwzględnieniu transferów spolecznych w krajach Unii Europejskiej

Źródło: jak na rysunku 1.

\section{Bezrobocie a ubóstwo}

Jedną z głównych przyczyn popadania w sferę ubóstwa jest bezrobocie. Przeciętna stopa bezrobocia w nowych krajach członkowskich była wyższa niż w krajach „starej" Unii. Największy poziom bezrobocia wystappił w Polsce i na Słowacji, gdzie prawie co piąta osoba pozostawała bez pracy. Wewnątrz poszczególnych państw stopa bezrobocia znacznie różni się pomiędzy regionami oraz obszarami miejskimi i wiejskimi.

Najmniejszy odsetek osób bezrobotnych miały Cypr i Węgry, a stopa bezrobocia była tam ponad dwa razy mniejsza niż przeciętna dla nowych krajów członkowskich. Bez pracy częściej pozostawały kobiety niż mężczyźni prawie we wszystkich krajach nowej „,dziesiątki" poza Węgrami i Estonia.

Siła wpływu bezrobocia na sytuacje dochodowa gospodarstw domowych zależy od płynności bezrobocia oraz przeciętnego okresu poszukiwania pracy. Im dłużej trwa okres bez pracy, tym bardziej pogarsza się sytuacja materialna osób bezrobotnych oraz ich rodzin. Długi okres pozostawania bez pracy ma również negatywny wpływ na możliwość ponownego zatrudnienia. Wskaźnik długotrwałego bezrobocia oblicza się jako procentowy udział w populacji aktywnych zawodowo osób pozostających bez pracy przez minimum 12 miesięcy. Poziom wskaźnika był w nowych krajach członkowskich ponaddwukrotnie większy w stosunku do pozostałych krajów Unii Europejskiej. Najgorsza sytuacja była na Słowacji, gdzie dwie trzecie osób bezrobotnych pozostawało bez pracy minimum 12 miesięcy. Najniższy poziom wskaźnika wystapił na Cyprze i Węgrzech i osiągnął wartość poniżej średniej z krajów byłej ,piętnastki”. 


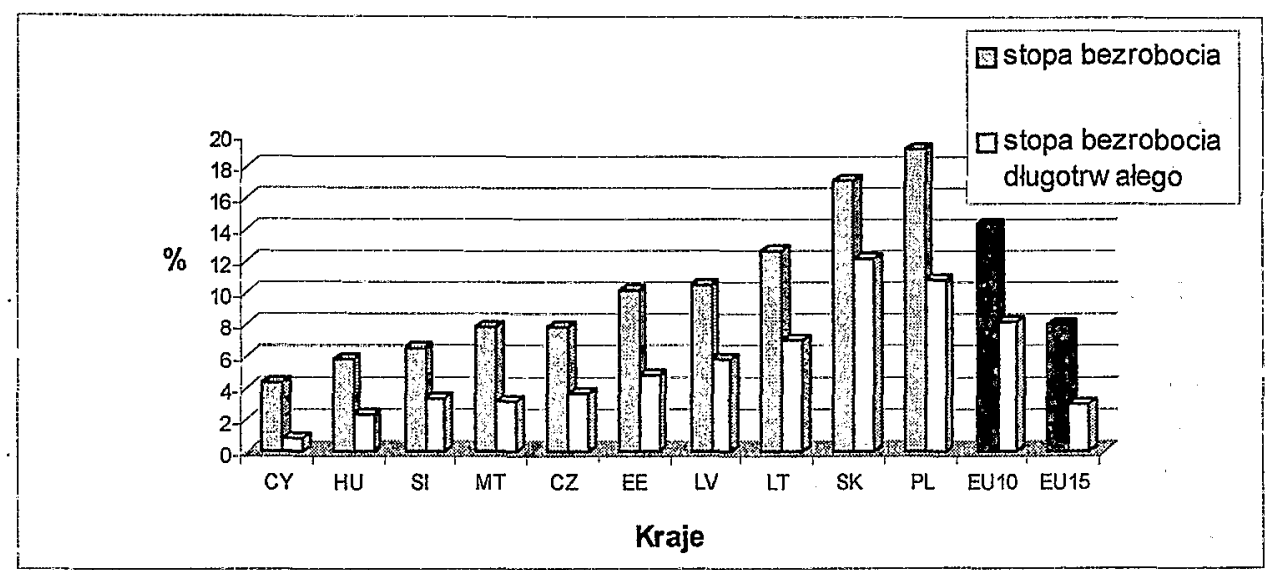

\section{Rysunek 6}

Stopa bezrobocia w nowych krajach członkowskich Unii Europejskiej w 2003 r.

Żródło: Commission of the European Communities; Commission Staff Working Paper, Social Inclusion in the New Member States, A Synthesis of the Joint Memoranda on Social Inclusion; Brussels, 22.6.2004 SEC (2004)848.

\section{Uwagi końcowe}

Dla większości nowych krajów członkowskich w Unii Europejskiej zwalczanie wykluczenia społecznego jest poważnym wyzwaniem. Proces transformacji doprowadził do obniżenia wydajności w gospodarce i wzrostu bezrobocia oraz nasilenia się wielu problemów ubóstwa w wielu regionach kraju oraz na obszarach wiejskich. W większości nowo przyjętych do Unii państw istnienie systemu zabezpieczenia społecznego odgrywało bardzo ważną rolę w zapobieganiu powiększaniu się ekstremalnego ubóstwa.

Poziom ubóstwa relatywnego w nowo przyjętych krajach Unii Europejskiej był bliski poziomowi pozostałych państw członkowskich. Jednakże gospodarstwa domowe żyjące poniżej granicy ubóstwa osiagały w nowej ,dziewiątce" zdecydowanie mniejsze dochody i dlatego zmagały się ze znacznie gorszymi warunkami bytu niż w krajach ,starej" Unii.

Do grup najbardziej zagrożonych popadnięciem w sferę ubóstwa należały rodziny wielodzietne i osoby samotnie wychowujace dzieci. Zła sytuacja finansowa gospodarstw domowych staje się jedną z najważniejszych barier w dostępie do edukacji dzieci i młodzieży oraz może negatywnie wpływać na ich rozwój fizyczny i emocjonalny.

Transfery społeczne odgrywały we wszystkich nowo przyjętych krajach bardzo duże znaczenie w zapobieganiu ubóstwu. Przeciętnie zmniejszyły one 
trzykrotnie sfere niedostatku. Jednakże transfèry społeczne są dużym obciążeniem dla budżetów państw i obecnie zwraca się większą uwagę na aktywne instrumenty zwalczania zjawișka pauperyzacji.

Jedną $\mathrm{z}$ głównych przyczyn ubóstwa było w nowych krajach członkowskich bezrobocie, zwłaszcza dhugotrwałe. Długi okres pozostawania bez pracy ma silny wpływ na sytuację dochodową gospodarstw domowych, a w nowych krajach członkowskich bezrobocie długotrwałe było na wysokim poziomie.

Polityka zwalczania ubóstwa i wykluczenia społecznego polega przede wszystkim na przeciwdziałaniu głównym przyczynom ich powstawania. Należy do niej zmniejszanie bezrobocia, zwłaszcza długotrwałego. Nie jest to zadanie łatwe i zapewne nie będzie osiągnięte w krótkim okresie. W dostępie do pracy dużą rolę odgrywają szkolenia oraz kształcenie ustawiczne. Jednocześnie posiadanie pracy nie gwarantuje wydostania się ze sfery ubóstwa, ze względu na niskie płace. W realizacji strategii przeciwdziałania ubóstwu i wykluczeniu społecznemu powinny wziąć zatem udział wszystkie instytucje. Coraz częściej podkreśla się rolę organizacji pozarządowych w realizacji zadań państwowych.

\section{Literatura}

„Armut und soziale Ausgrenzung in der EU nach Laeken Teil 1”, Statistik kurz gefasst. Bevölkerung und soziale Bedingungen, THEMA 3-8/2003, Eurostat 2003.

"Armut und soziale Ausgrenzung in der EU nach Laeken Teil 2", Statistik kurz gefasst. Bevölkerung und soziale Bedingungen, THEMA 3-9/2003, Eurostat 2003.

Commission of the European Communities; Commission Staff Working Paper, Social Inclusion in the New Member States, A Synthesis of the Joint Memoranda on Social Inclusion; Brussels, 22.6.2004 SEC (2004)848.

Narodowa Strategia Integracji Społecznej dla Polski - dokument przygotowany przez Zespół Zadaniowy do spraw Reintegracji Społecznej, któremu przewodniczył Minister Gospodarki, Pracy i Polityki Społecznej Jerzy Hausner.

STAŃKO A., Wykluczenie społeczne i sfera ubóstwa w krajach Unii Europejskiej. Zeszyty Naukowe SGGW, Ekonomika i Organizacja Gospodarki Żywnościowej, Nr 50 (2003).

\section{The Poverty Level in New Member Countries of the European Union}

\section{Abstract}

The paper presents chosen indicators of poverty and labour market in new member countries of the European Union. The new member countries could participate in the open coordination of policy against poverty and social exclusion from the first day of membership. 
The poverty level in new member countries was almost on the same level as in the "old" members but the poverty threshold was much lower in new members. The biggest sphere of poverty was in Estonia and Lithuania (over $16 \%$ ), the lowest - in the Czech Republic and Hungary (about 10\%).

The main cause of poverty in all of the member countries was unemployment, especially persistent. 
